\title{
KUALITAS FISIK, KIMIA DAN BAKTERIOLOGISAIR KOLAM RENANG DI WILAYAH KECAMATAN MADIUN KABUPATEN MADIUN
}

Finna Pramita Rahayu, Prijono Sigit, Susi Nurweni

\begin{abstract}
ABSTRAK
Pengawasan kualitas air kolam renang perlu dilakukan terus mnerus agar tidak menimbulkan gangguan kesehatan terhadap pengunjung misalnya penyakit kulit, mata. Penelitian ini bertujuan untuk mengetahui kualitas fisik, kimia (sisa Chlor) dan bakteriologis air kolam renang di wilayah Kecamatan Madiun, Kabupaten Madiun.

Penelitian ini dilakukan pada tiga kolam renang dengan menggunakan metode diskriptif. Pengumpulan data dilakukan dengan observasi, wawancara dan pengambilan sampel air untuk pemeriksaan bakteriologis di laboratorium. Hasil penelitian dianalisis dengan cara membandingkan terhadap baku mutu Peraturan Menteri Kesehatan Nomor 416 tahun 1990

Hasil penelitian menunjukkan untuk kualitas fisik yang meliputi bau, benda terapung dan kejernihan dari tiga kolam renang yaitu Sentana Tirta, Tirta Hutama dan Permata Biru semuanya telah memenuhi syarat. Untuk sisa Chlor air kolam renang, dari pengukuran selama tiga hari hanya satu hari yang memenuhi syarat $(0,2 \mathrm{ppm})$, sedangkan dua hari yang lain tidak memenuhi syarat $(0,02-0,05 \mathrm{ppm})$. Hasil pemeriksaan laboratorium menunjukkan bahwa dari tiga kolam renang, jumlah angka kuman antara 550 - 24.000 koloni/ml, jauh melebihi baku mutu yang dipersyaratkan Permenkes No. 416 tahun 1990 yaitu 200 kolono/ml.

Berdasarkan hasil pemeriksaan kualitas air kolam renang tersebut perlu dilakukan pengawasan dan pemeriksaan hygiene dan sanitasi kolam renang secara berkala utamanya sisa Chlor dan kualitas bakteriologi.
\end{abstract}

Kata kunci : Kolam renang, kualitas kimia, bakteriologi

\section{PENDAHULUAN}

Kolam renang salah satu tempat umum yang dapat memungkinkan terjadinya penularan penyakit apabila sanitasi kolam renang tidak memenuhi syarat kesehatan, sehingga lingkungan tempat umum harus dijaga untuk mencegah kemungkinan terjadinya penularan penyakit baik langsung dan tidak langsung. Hal ini dinyatakan dalam UU No 36 Tahun 2009 tentang kesehatan Bab IX Pasal 163 ayat 2 menyatakan bahwa " Lingkungan sehat sebagaimana yang dimaksud pada ayat 1 yaitu mencakup lingkungan pemukiman, tempat kerja, tempat rekreasi, serta tempat dan fasilitas umum.

Air kolam renang dapat menyebarkan penyakit seperti penyakit kulit, Typus abdominalis, Dysentri, Polio dan juga yang paling utama dapat menimbulkan iritasi pada mata manusia. Oleh karena itu air yang digunakan dalam kolam renang harus memenuhi persyaratan kualitas fisik, kimia dan bakteriologis yang sudah diatur dalam Peraturan

KesehatanRINo.416/Menkes/Per/IX/1990 tentang persyaratan kualitas air kolam renang.

Wilayah Kecamatan Madiun terdapat tiga buah kolam renang yaitu Kolam Renang Sentana Tirta terletak di Desa Dempelan,
Kolam Renang Tirta Hutama terletak di Desa Banjarsari dan Kolam Renang Permata Biru yang terletak di Desa Banjarsari. Berdasarkan hasil observasi pada Kolam Renang di wilayah Kecamatan Madiun diperoleh hasil ada Kolam Renang yang tidak memenuhi persyaratan sanitasi kolam renang Sentana Tirta berupa kualitas fisik yaitu adanya benda terapung dan kejernihan yang tidak memenuhi persyaratan. Ditinjau dari kualitas kimia yaitu terdapatnya sisa chlor nya tidak memenuhi persyaratan air kolam renang, untuk persyaratan bangunan dan fasilitas sanitasi terdapat satu kolam renang yang tidak memiliki pancuran (shower) dan juga tidak tersedia bak cuci kaki. Selain itu, perilaku pengunjung yang tidak membilas diri sebelum dan sesudah berenang juga menjadi penyebab kualitas air kolam renang menjadi menurun.

\section{METODE PENELITIAN}

Penelitian ini dilaksanakan menggunakan metode deskriptif yaitu suatu metode penelitian yang dilakukan dengan tujuan utama untuk membuat gambaran atau deskripsi tentang suatu keadaan secara objektif (Soekidjo Notoatmojo, 2005). Metode penelitian deskriptif karena bertujuan memperoleh pemaparan yang 
objektif tentang kualitas air kolam renang di wilayah Kecamatan Madiun.

Sampel yang dipakai dalam penelitian ini adalah air kolam renang di Wilayah Kecamatan Madiun. Data yang diperoleh dari hasil observasi Kolam Renang yang meliputi Kualitas fisik, kimia, dan bakteriologis disajikan dalam bentuk tabel.

\section{HASIL PENELITIAN DAN PEMBAHASAN}

Analisa data dideskripsikan dengan menganalisis hasil lapangan dan hasil laboratorium kemudian dibandingkan dengan Peraturan Menteri Kesehatan Nomor 416 Tahun 1990 tentang Syarat-syarat Dan Pengawasan Kualitas Air.

\section{Kolam Renang Sentana Tirta}

Alamat

Jumlah Kolam Renang

Ukuran Kolam Renang Dewasa

Ukuran Kolam Renang Remaja

Ukuran Kolam Renang anak-anak

Tiket Masuk Pengunjung

Jumlah Pengunjung

Cara Pengisian

Sumber air kolam renang

Cara Pengurasan

Cara Pemberian Desinfektan
: $\quad$ Ds. Dempelan Kec. Madiun Kab. Madiun

$$
3
$$

$25,2 \mathrm{~m} \times 12,8 \mathrm{~m}, 1,3-1,5 \mathrm{~m}=451,584 \mathrm{~m}^{3}$

$15 \mathrm{~m} \times 10 \mathrm{~m}, 0,8-0,9 \mathrm{~m}=127.500 \mathrm{~m}^{3}$

$14 \mathrm{~m} \times 10 \mathrm{~m}, 0,5-0,7 \mathrm{~m}=84.000 \mathrm{~m}^{3}$

Dewasa Rp.5000 dan anak- anak Rp.3.000

Rata-rata 10-20 orang per hari.

Menggunakan sistem fill draw pools.

Berasal dari air tanah

Dilakukan secara manual, pada hari Senin dan Kamis.

Menabur kaporit dengan takaran 3 rantang yang dilakukan setelah pengurasan. 1 rantang $=600 \mathrm{gram}$. Berarti jika 3 rantang $=3$ x 600 gram $=1800$ gram

Ds. Banjarsari Kec. Madiun Kab. Madiun

2

$22 \mathrm{~m} \times 16 \mathrm{~m}, 1,3 \mathrm{~m}-2 \mathrm{~m}=580.800 \mathrm{~m}^{3}$

$11,2 \mathrm{~m} \times 4,5 \mathrm{~m}, 0,8 \mathrm{~m}-0,9 \mathrm{~m}=42.840 \mathrm{~m}^{3}$

Dewasa Rp.5.000 dan anak. - anak Rp.3.000

Rata-rata 5 - 10 orang per hari.

Menggunakan sistem fill draw pools

Berasal dari air tanah

Dilakukan secara manual pada hari Kamis.

Menabur kaporit dengan takaran 2 rantang yang dilakukan setelah pengurasan. 1 rantang $=600$ gram.

Berarti jika 2 rantang $=2 \times 600$ gram $=1200$ gram

\section{Kolam renang Permata Biru}

Alamat

Jumlah Kolam Renang

Ukuran Kolam Renang Dewasa

Ukuran Kolam Renang Remaja

Ukuran Kolam Renang anak-anak

Tiket Masuk Pengunjung

Jumlah Pengunjung

Cara Pengisian

Sumber air kolam renang

Cara Pengurasan

Cara Pemberian Desinfektan
Ds. Banjarsari Kec. Madiun Kab. Madiun

3

$16 \mathrm{~m} \times 8 \mathrm{~m}, 1,3-1,5 \mathrm{~m}=179.200 \mathrm{~m}^{3}$

$15 \mathrm{~m} \times 7 \mathrm{~m}, 0,8-1 \mathrm{~m}=36.400 \mathrm{~m}^{3}$

$13 \mathrm{~m} \times 7 \mathrm{~m}, 0,5-0,7 \mathrm{~m}=94.500 \mathrm{~m}^{3}$

Dewasa Rp.5000 dan anak. - anak Rp.3.000

Rata-rata 10-20 orang per hari.

Menggunakan sistem fill draw pools.

Berasal dari air tanah.

Dilakukan secara manual di Bulan Desember tetapi di vacum cleaner setiap hari.

: Menabur kaporit dengan takaran 3 rantang yang dilakukan setelah pengurasan. Berarti jika 3 rantang $=3$ x 600 gram $=1800$ gram 


\section{Kualitas Fisik meliputi Bau, Kejernihan dan Benda Terapung}

\section{Bau}

Dari ketiga Kolam Renang yaitu Sentana Tirta dan Tirta Hutama dan Permata Biru ditinjau dari aspek fisik untuk parameter bau sudah memenuhi syarat, hal ini ditunjukkan oleh tidak adanya bau dari badan air kolam renang. Berdasarkan Permenkes No. 416 Tahun 1990, air kolam renang disyaratkan untuk tidak berbau. Bau yang dimaksudkan adalah bau yang mengganggu, seperti bau busuk atau bau tidak wajar yang tidak seharusnya, maupun bau chlorin. Air yang berbau busuk mengandung bahan-bahan organik yang sedang mengalami dekomposisi (penguraian) oleh mikroorganisme air.

\section{Kejernihan}

Dari ketiga Kolam renang yaitu Kolam renang Sentana Tirta, Tirta Hutama dan Permata Biru ditinjau dari aspek kualitas fisik yaitu kejernihan sudah memenuhi syarat, hal ini ditunjukkan dengan terlihatnya piringan sechi yang diletakkan pada kolam bagian yang paling dalam dan dapat dilihat dari jarak lurus $9 \mathrm{~m}$. Aspek kualitas fisik untuk parameter kejernihan sudah diatur di dalam Peraturan Menteri Kesehatan Republik Indonesia No.416/MENKES/PER/IX/1990, air kolam renang harus selalu terlihat jernih, tidak boleh keruh. kekeruhan air disebabkan oleh zat padat yang tersuspensi, baik bersifat organik maupun non organik. Zat anorganik biasanya berasal dari lapukan batuan atau logam sedangkan zat organik berasal dari lapukan tanaman atau hewan. Bakteri ini juga merupakan zat organik tersuspensi, sehingga pertambahannya juga akan menambah kekeruhan air. Demikian pula dengan algae yang berkembang biak dengan adanya zat hara akan menambah kekeruhan air.

Kekeruhan pada air merupakan satu hal yang harus dipertimbangkan dalam penyediaan air bagi umum, mengingat bahwa kekeruhan tersebut akan mengurangi segi estetika, menyulitkan dalam usaha penyaringan, dan akan mengurangi efektivitas usaha desinfeksi. Air yang keruh akan sulit didesinfeksi, karena mikroba akan terlindung oleh zat tersuspensi tersebut. Hal ini akan berbahaya bagi kesehatan, apabila mikroba tersebut patogen. Dampak dari air yang tidak jernih dapat menyebabkan mata merah dan gatal-gatal karena kondisi air yang kurang baik dan kotor.

\section{Benda Terapung}

Dari tiga Kolam renang di Kecamatan Madiun Kabupaten Madiun, dua Kolam renang Sentana Tirta dan Permata Biru untuk parameter benda terapung sudah memenuhi syarat, tetapi pada kolam renang Tirta Hutama tidak memenuhi syarat. Peraturan Menteri Kesehatan Republik IndonesiaNo.416/MENKES/PER/IX/1990 tentang Persyaratan Kualitas air, air kolam renang tidak boleh terdapat benda terapung. Ini dikhawatirkan terdapatnya benda terapung di air kolam renang, selain mengganggu estetika kolam renang juga bisa mengurangi kenyamanan dan membahayakan bagi perenang itu sendiri.

\section{Kualitas Kimia: pH dan Sisa chlor pH ( Phose Hidrogen)}

Hasil pemeriksaan dari ketiga Kolam renang didapatkan hasil $\mathrm{pH}$ air kolam renang sebesar 7. Berdasarkan Peraturan Menteri Kesehatan Republik Indonesia No.416/MENKES/PER/IX/1990, pH 6,5 - 8,5. Nilai $\mathrm{pH}$ dapat mempengaruhi parameter kimia lain, seperti sisa chlor dan kesadahan. Tingkat $\mathrm{pH}$ pada air kolam renang akan menyebabkan klorin dalam air cepat larut. $\mathrm{pH}$ rendah akan menyebabkan ion logam menimbulkan korosi dan meninggalkan noda di dinding dan lantai kolam. Namun apabila $\mathrm{pH}$ tinggi dalam air kolam renang dapat menyebabkan pertumbuhan abnormal alga yang pada gilirannya menyumbat filter air kolam renang. Air berwarna agak kusam atau berawan dan keputih putihan. Efek pada manusia bisa menyebabkan mata perih, kulit kering.

\section{Sisa Chlor}

Berdasarkan hasil permeriksaan kualitas kimia untuk parameter sisa chlor air kolam renang Sentana Tirta, yang memenuhi syarat hanya pada tanggal 13 Mei pada kolam anak - anak yaitu 0,2, sedangkan air kolam renang yang lain tidak memenuhi syarat . Pada Kolam Renang Tirta Hutama yang memenuhi syarat hanya pada kolam renang anak - anak dan dewasa 0,2. Kolam Renang Permata Biru yang memenuhi syarat hanya pada kolam renang anak - anak 0,3, sedangkan yang lain tidak memenuhi syarat. Rendahnya sisa chlor ini disebabkan karena belum ada perhitungan volume air, perhitungan daya sergap chlor, dan juga perhitungan zat chlorine.

Dengan sisa chlor yang demikian dapat menjadi media yang baik untuk perkembangbiakan mikroorganisme sehingga kolam renang sebagai media penularan penyakit. Selain itu, apabila kandungan 
chlorin berkurang maka dapat menimbulkan pertumbuhan lumut, pertumbuhan binatang dalam air seperti jentik nyamuk dan air kolam cenderung akan hijau dan cepat berubah warna. Demikian pula apabila sisa chlor tinggi (di atas 0,5 ppm) juga tidak diperbolehkan. Apabila sisa chlor tinggi dalam air kolam renang dapat menyebabkan air cenderung bau, pedih di mata, iritasi kulit seperti gatal. Cara menanggulangi agar chlor tidak terlalu tinggi bisa dengan cara menambahkan tawas secukupnya atau dengan larutan Sodium Bisulfate (HCL) tentunya dengan takaran yang dianjurkan.

\section{Kualitas Bakteriologis}

Dari ketiga Kolam renang yaitu kolam renang Sentana Tirta, Tirta Hutama dan Permata Biru yang ditinjau dari aspek kualitas bakteriologis untuk parameter angka kuman tidak memenuhi syarat. Hasil pemeriksaan kualitas bakteriologis parameter angka kuman air kolam renang Sentana Tirta pada pengiriman sampel tanggal 15 Mei 2015, air kolam 1 didapatkan hasil angka kuman 6300 koloni/ml sedangkan air kolam renang 2 didapatkan hasil angka kuman 760 koloni/ml, dan kolam 3 didapatkan hasil angka kuman 550 koloni/ml.

Hasil pemeriksaan angka kuman pada air kolam renang Tirta Hutama pada kolam 1 didapatkan hasil 7.500 koloni dan kolam 2 didapatkan hasil 13.500 koloni $/ \mathrm{ml}$. Kolam renang Permata Biru untuk parameter angka kuman didapatkan hasil 5.300, sedangkan kolam 2 didapatkan hasil 11.500 dan kolam 3 didapatkan hasil 24.000 .

Sesuai Peraturan Menteri Kesehatan No. 416/Menkes/Per/IX/1990 bahwa air kolam renang harus negatif dari keberadaan bakteri total coliform dan angka kuman tidak boleh melebihi 200 koloni/ml.

\section{Kesimpulan}

Berdasarkan hasil penelitian yang telah diuraikan, maka dapat disimpulkan sebagai berikut :

1. Ditinjau dari kualitas fisik, kedua kolam renang telah memenuhi syarat, untuk kolam renang Tirta Hutama pada parameter benda terapung tidak memenuhi syarat

2. Persyaratan $\mathrm{pH}$ dari ketiga kolam renang sudah memenuhi syarat yaitu 7. Untuk sisa chlor yang memenuhi syarat hanya pada kolam renang Sentana Tirta pada tanggal 13 Mei 2015, Tirta Hutama pada tanggal 13 Mei 2015, Permata Biru tanggal 13 Mei di kolam renang anakanak, sedangkan yang lainnya tidak memenuhi syarat yaitu 0,02- 0,05 Ppm.
3. Pemeriksaan kualitas bakteriologis air Kolam Renang Sentana Tirta, Tirta Hutama dan juga Permata Biru didapatkan hasil jumlah angka kuman tidak memenuhi syarat yaitu lebih dari 200 koloni/ml.

4. Berdasarkan hasil pengamatan, pengukuran dan pemeriksaan kualitas air Kolam Renang Sentana Tirta, Tirta Hutama, Permata Biru secara umum kualitas air kolam renang tidak memenuhi syarat sesuai Peraturan Menteri Kesehatan RI No.416/MENKES/PER/IX/1990.

\section{Saran}

Bagi Pengelola Kolam Renang disarankan untuk meningkatkan pengawasan hygiene sanitasi kolam renang secara rutin dan terus menerus. Selain itu perlu dilakukan pemberian desinfektan dengan dosis yang tepat untuk mencegah pertumbuhan bakteri di air kolam renang.

\section{Daftar Pustaka}

Alvian, Rahmat, 2013. Studi Tentang Kualitas Air Kolam Renang Tirta Woelandari Kaligunting Kabupaten Madiun Tahun 2013. Karya tulis ilmiah Program studi Kesehatan Lingkungan Kampus Magetan Poltekkes Surabaya. Magetan.

Anonymous. 2009 .Persyaratan Kesehatan Lingkungan Kolam Renang dan Pemandian Umum.

Isnanto, 2010. Sistem Instalasi Kolam Renang. Diakses pada 25-02-2015

Notoatmodjo, Soekidjo, 2005. Metodologi Penelitian Kesehatan. Jakarta.

Peraturan Kesehatan Republik Indonesia, 1991. Persyaratan kesehatan kolam renang dan pemandian umum.

Satoto Yogi, Kumalasari Fety, 2011. Teknik Praktis Mengolah Air Kotor Menjadi air bersih hingga layak diminum. Halaman 7

Setiowati, Riska, 2011. Jurusan Kesehatan Masyarakat Fakultas Kesehatan Masyarakat Universitas Jember mengenai Gambaran Sanitasi Kolam Renang dan Pemandian Umum di Kabupaten Kabupaten Jember. http://repository.unej.ac.id/handle/123 456789/3322

Sulityaningsih, 2011. Metodologi Penelitian Kesehatan. Jakarta.

Suparlan, 1988. Pedoman Pengawasan Sanitasi Tempat-Tempat Umum. Halaman 107. PT. Surabaya Medika Print. 